\title{
Catheter Thoracostomy: Our 5 Years of Clinical Experience
}

\section{Katater Torakostomi: 5 Y॥lık Klinik Deneyimimiz}

\author{
Mehmet Akif TEZCAN ${ }^{1}$ (D), ibrahim Ethem ÖZSOY ${ }^{1}$ \\ ${ }^{1}$ Department of Thoracic Surgery, Kayseri Health Practice and Research Center, University of Health Sciences, Kayseri, TURKEY
}

\section{Abstract}

Background: It was aimed to retrospectively examine the data of patients who underwent catheter thoracostomy to determine their demographic and clinical characteristics and to evaluate the effectiveness of the procedure.

Materials and Methods: We retrospectively evaluated 613 catheter thoracostomy procedures performed at the Health Practice and Research Center between January 1, 2013 and December 31, 2017.

Results: Five hundred and sixty-seven $(92.5 \%)$ were unilateral and $46(7.5 \%)$ were bilateral catheter thoracostomy. Three hundred and seventy-seven $(61.5 \%)$ procedures were performed on male patients and $236(38.5 \%)$ procedures were performed on female patients. The mean age was $68 \pm 16$ (13-105 years old). The operation indications were 202 (33\%) thoracic malignancies, 98 (16\%) extrathoracic malignancies, and benign pathologies in 313 (51\%) patients.

Conclusions: Catheter thoracostomy procedure is being used more and more every day in the treatment of pleural effusions due to patient comfort, ease of application and low cost.

Key Words: Effusion, Catheter thoracostomy, Pleura

Öz.

Amaç: Kateter torakostomi uygulanan hastaların verilerini retrospektif olarak inceleyerek demografik ve klinik özelliklerini belirlemek ve işlemin etkinliği ile ilgili değerlendirmelerde bulunmak amaçlandı.

Materyal ve Metod: 1 Ocak 2013- 31 Aralık 2017 tarihleri arasında Sağılı Uygulama ve Araştırma Merkezinde uygulanan 613 adet kateter torakostomi işlemini retrospektif olarak değerlendirdik.

Bulgular: Beş yüz altmış yedi (\%92.5)'si unilateral, 46 (\%7.5)'sı ise bilateral kateter torakostomi idi. Üç yüz yetmiş yedi (\%61.5) işlem erkek hastalara, 236 (\%38.5) işlem ise kadın hastalara yapıldı. Ortalama yaş $68 \pm 16$ (13-105 yaş aralığında) idi. İşlem endikasyonları ise 202 (\%33) torasik malignensiler, 98 (\%16) ekstratorasik malignensiler, 313 (\%51) hastada ise benign patolojilerdi.

Sonuç: Kateter torakostomi işlemi plevra efüzyonların tedavisinde hasta konforu, uygulama kolaylı̆̆ ve düşük maliyet nedeniyle her geçen gün daha fazla kullanılmaktadır.

Anahtar kelimeler: Efüzyon, Kateter torakostomi, Plevra
Corresponding Author/Sorumlu Yazar

Dr. Mehmet Akif TEZCAN

Department of Thoracic Surgery, Kayseri Health Practice and Research Center, University of Health Sciences, Kayseri, TURKEY

E-mail: mehmetakiftercan@gmail.com

Received / Geliş Tarihi: 23.02.2021

Accepted / Kabul Tarihi: 01.06.2021

DOI: $10.35440 /$ hutfd. 885671 


\section{Introduction}

Catheter thoracostomy is a percutaneous application of a small-diameter catheter to drain the air and fluid accumulated in the thoracic cavity. Similar to tube thoracostomy, it is indicated in many different conditions, such as pneumothorax and pleural fluid with the main objective of providing drainage of the pleural cavity. Today, it is applied more frequently when compared with tube thoracostomy because it provides more comfortable treatment options, such as easier bed-side application, no requirement of additional surgical instruments at the time of application and less pain felt by the patient. However, because the catheters are smaller and more flexible, complications such as change in location, bending, slipping or dislocation of the catheter are more commonly observed. Additionally, there is an opinion that it is not effective enough in the treatment of pneumothorax, as there are problems with correct insertion of the catheter tip into the apex. Although the application is perceived as a simple and technically easy procedure, it can challenge even experienced thoracic surgeons in obese patients and patients with pleural effusion; therefore, it is an operation that is always open to serious complications (1-7).

We aimed to retrospectively examine the data of patients who underwent catheter thoracostomy in our clinic, to determine the demographic and clinical characteristics of the patients and to evaluate the effectiveness of the procedure.

\section{Materials and Methods}

Ethics committee approval was obtained from Local Ethics Committee (Adana city training and research hospital Clinical research ethics committee. Date: 06/19/2018, Decision Nr: 14-212). The study was planned retrospectively. Patients who underwent catheter thoracostomy in our clinic and intensive care units for any reason during the 5year period between January 1, 2013 and December 31, 2017 were included in the study. Intervention on all patients was performed by thoracic surgery specialists. To access the data of the patients from the hospital information management system, permission was obtained from the specialty in medicine education board and the data were analysed retrospectively. The demographic data of the patients were evaluated in terms of indication for catheter thoracostomy, duration of stay, clinical findings, complications and total length of hospitalisation.

Pleurocan $^{\circledR}$ (B.Braun, Melsungen, Germany) was used as the catheter for catheter thoracostomy.

Pleurocan ${ }^{\circledR}$ is a polyurethane radiopaque catheter with 8-

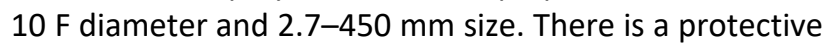
sheath around the catheter. The outer cannula is 3.35-78 $\mathrm{mm}$ in diameter. It includes a two-way faucet, double valve spacer, drain bag and $60 \mathrm{~mm}$ injector parts. In terms of technique, the operations were performed bed-side for all patients. Fluid location was confirmed by physical ex- amination and posteroanterior and lateral lung radiographies of the patient. The patient was placed in a semi-

sitting or upright position and the arm was removed from the surgical field and was placed on the head. The operation area was widely dyed with an antiseptic solution. After determining the intercostal space where the procedure was to be performed, local anaesthesia was administered with prilocaine to the skin, subcutaneous tissues, muscles and parietal pleura. Next, the catheter's cannula was passed through the skin and subcutaneous tissues, and the skin was entered perpendicularly from the upper edge of the rib. When it was felt to pass the pleura, the cannula was kept fixed and the catheter was advanced through it. Next, the cannula was removed, a triple tap was placed on the proximal end of the catheter, an injector was inserted into the other tap inlet, air or fluid was aspired and the catheter was positioned appropriately. The catheter was fixed to the skin with 2-0 silk sutures. The catheter was connected to an underwater drain or drain bag. Catheter position was checked with posteroanterior and lateral chest radiographs immediately after the procedure. Patients were followed-up with monitoring of daily drainage measurements and control radiographs. The catheter was removed upon completion of air release and there was less than $50-100 \mathrm{ml}$ of fluid drainage per day, chest radiography revealed expansion of the lungs (Figure1). In cases of empyema, it was ensured that there was no growth in the fluid culture after the treatment, the fluid colour was clear and the daily drainage amount was less than 50-100 $\mathrm{ml}$. The catheter was terminated after pleurodesis with talc in cases with malignant pleural effusion.

Coding and statistical analysis of the data were performed using the IBM SPSS 22 package programme. The numerical values obtained from the patients were expressed as mean \pm standard deviation (mean $\pm s d$ ), and categorical values were expressed as median \pm minimum maximum (median \pm min-max). Additionally, mean $\pm s d$ and median \pm min-max values were visualised by column or line charts.

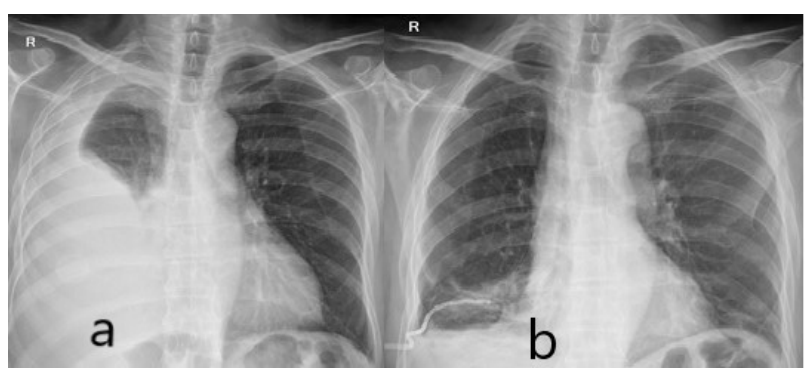

Figure 1. a. Chest radiography of the patient with pleural effusion; b. Chest radiography after catheter procedure.

\section{Results}

In the 5-year period between January 1, 2013 and December 31, 2017 , total of 613 catheter thoracostomy procedures were performed. Out of these, 567 (92.5\%) were unilateral and 46 (7.5\%) 
were bilateral catheter thoracostomies. Further, 377 (61.5\%) procedures were performed on men patients and 236 $(38.5 \%)$ were performed on women patients. The mean age was $68 \pm 16(13-105)$ years. The indications for the procedure were thoracic malignancies in 202 (33\%) patients, extrathoracic malignancies in $98(16 \%)$ patients and benign pathologies in 313 (51\%) patients. Catheter thoracostomy duration was $0-3$ days in 194 patients (31.7\%) procedures, 4-7 days in 151 (24.6\%) procedures, 8-14 days in 130 patients $(21.2 \%)$ procedures and more than 15 days in 138 (22.5\%) procedures. Complications due to catheter thoracostomy were observed in 41 patients (6.7\%). All demographic data, aetiology, indications and complications of catheter thoracostomy procedures are presented in Table 1.

Table 1. Patient's characteristics (Demographic data, aetiology, indications and complications)

\begin{tabular}{|c|c|}
\hline Data & $\mathrm{n}(\%)$ \\
\hline Number of patients & 613 \\
\hline \multicolumn{2}{|l|}{ Age (years) } \\
\hline Median \pm SD & $68 \pm 16$ \\
\hline Range & 13-105 \\
\hline \multicolumn{2}{|l|}{ Gender } \\
\hline Men & $377(61.5 \%)$ \\
\hline Women & $236(38.5 \%)$ \\
\hline \multicolumn{2}{|l|}{ Etiologies } \\
\hline Malignancies & $300(49 \%)$ \\
\hline Thoracic malignancies & $202(33 \%)$ \\
\hline Lung cancer & $154(25.1 \%)$ \\
\hline Mesothelioma & $28(4.6 \%)$ \\
\hline Lymphoma & $20(3.3 \%)$ \\
\hline Extrathoracic malignancies & $98(16 \%)$ \\
\hline Breast cancer & $66(10.8 \%)$ \\
\hline Gastric cancer & $10(1.6 \%)$ \\
\hline Pancreas cancer & $5(0.8 \%)$ \\
\hline Colorectal cancer & $12(2 \%)$ \\
\hline Over cancer & $5(0.8 \%)$ \\
\hline Benign pathologies & $313(51 \%)$ \\
\hline Trauma & $10(1.6 \%)$ \\
\hline Congestive heart failure & $92(15 \%)$ \\
\hline Cirhosis & $32(5.2 \%)$ \\
\hline Parapneumonic effusion/ empyema & $163(26.6 \%)$ \\
\hline Tuberculosis & $13(2.1 \%)$ \\
\hline Chylothorax & $3(0.5 \%)$ \\
\hline \multicolumn{2}{|l|}{ Laterality } \\
\hline Unilateral thoracostomy & $567(92.5 \%)$ \\
\hline Bilateral thoracostomy & $46(7.5 \%)$ \\
\hline \multicolumn{2}{|l|}{ Thoracostomy time } \\
\hline $0-3$ days & $194(31.7 \%)$ \\
\hline 4-7 days & $151(24.6 \%)$ \\
\hline 8-14 days & $130(21.2 \%)$ \\
\hline $15 \geq$ days & $138(22.5 \%)$ \\
\hline Complications & $41(6.7 \%)$ \\
\hline Subcutaneous emphysema & $15(2.4 \%)$ \\
\hline Wound site infection & $6(1 \%)$ \\
\hline Positional complications (king, etc) & $8(1.3 \%)$ \\
\hline Pneumothorax & $12(2 \%)$ \\
\hline Length of stay (days) & $9.91 \pm 11.4$ \\
\hline
\end{tabular}

\section{Discussion}

Since pleural fluid usually develops secondary to a disease, its incidence cannot be exactly determined. In studies conducted by examining regional and country official records, an incidence of 3-5 cases/1000 people/year was reported (8). More than 1,360,000 cases with pleural fluid are expected annually in the United States of America (USA) (9). When the causes of death in the USA are examined at age-standardised rates, mortality rate of pleural fluid is generally reported as 0.3 per 100,000 ( 0.4 for men and 0.3 for women). Pleural fluid develops in $25 \%-50 \%$ of patients with congestive heart failure, pneumonia, malignant disease or pulmonary embolism (10). Therefore, approximately $20 \%$ of patients admitted to Thoracic Diseases clinics are patients with pleural fluid. The prevalence of pleural fluids in intensive care patients depends on the diagnostic methods used. While the prevalence of pleural fluid in patients hospitalised in intensive care units is around $8 \%$ with physical examination, this rate increases to $60 \%$ when ultrasonography is used for diagnosis. Drainage with a pleural catheter is performed and chemical pleurodesis can be performed in pleural effusions with development of dyspnoea, massive pleural effusions and in recurrent pleural effusions which do not respond to cause targeted-therapy. Generally, thoracic drainage systems smaller than 20 French (F) diameter are used as pleural catheters. Small-diameter thoracic catheters used in catheter thoracostomy are available in literature with different names, products and diameters, such as pigtail catheters (7-8.5F, Cook Critical Care; Cook Incorporated; Bloomington, IN), Pleurocan ${ }^{\circledR}$ (8-10F, B. Braun, Melsungen, Germany) and Pleurx ${ }^{\mathrm{TM}}$ (15.5F, Care- Fusion, San Diego, CA, USA).

Being appropriate and convenient for fluid therapy, bedside-application, easy and painless insertion, enabling less painful procedure and follow-up, enabling pleurodesis application in malignant pleural effusions, shortening the duration of hospitalisation, having low complication rates, patient or relatives being able to perform drain control at home and low cost are the factors affecting the use of pleural catheters in catheter thoracostomy (1,2,11-14). The disadvantage is that when used in cases with empyema, it gets blocked easily due to the mucoid content of the fluid and accumulated fibrin materials.

In our study, the duration of catheter stay was 0-3 days in $31.7 \%, 4-7$ days in $24.6 \%, 8-14$ days in $21.2 \%$ and more than 15 days in $22.5 \%$ of patients who had insertion of pleural catheters. Mean hospitalisation duration was 9.91 \pm 11.4 days. In 445 patients who underwent tube thoracostomy due to pleural effusion in the study we conducted in the same period, the duration of tube stay was 0-3 days in $28.98 \%$ (129), 4-7 days in 29.66\% (132), 8-14 days in $21.57 \%$ (96) and more than 15 days in $18.87 \%$ (84) of patients who had insertion of tube thoracostomy. Mean hospitalisation duration was $10.41 \pm 12.4$ days. There was no statistically significant difference between 
the two groups ( $p>0.05)$.

We did not use indwelling pleural catheters in any of our patients. We applied talc pleurodesis through the same catheter in malign effusions.

Since the complication rates are higher compared to other patients, attention should be paid to patients with bleeding diathesis, surgical history (cardiac, intrathoracic), previous pleurodesis history, insertion of recurrent pleural catheters, thoracentesis history and immunosuppressed patients. Despite its many advantages, there is a slight risk of morbidity and mortality (1,15-17).

Complications are observed in approximately $5 \%-10 \%$ of patients in pleural catheter applications $(15,17)$. These rates are similar to the complication rate seen due to tube thoracostomy (15). Complications are largely divided into two types: early and late. The early complications are pneumothorax, hemothorax, extrapleural placement of drain, pain, hypotension and organ injury, whereas the late complications are pain, ejection of the drain, blockage of the drain, subcutaneous emphysema, folding of the drain on itself, drain rupture, infection (skin or pleural), reexpansion of pulmonary oedema and death $(15,16)$.

In our study, complications were observed in 41 patients (6.7\%). Pneumothorax developed in 12 of these patients iatrogenically or due to the patient's negligence toward catheter connection and disconnection of the catheter. Among the patients who developed pneumothorax, 4 patients were treated with Pleurocan ${ }^{\circledR}$ underwater drainage, whereas 8 patients underwent tube thoracostomy. Fifteen patients developed subcutaneous emphysema and were monitored with nasal oxygen and daily chest radiography. Tube thoracostomy was performed on 8 patients because the catheter could not drain the dense pleural fluid content due to kinking. Wound infection developed in 6 patients. Procedure-related mortality did not occur in our study.

\section{Conclusion}

Pleural catheters are increasingly used in the treatment of pleural effusions due to patient comfort, ease of application and low cost. When the appropriate patient is selected, it is as effective as tube thoracostomy.

Ethical Approval: The subjects (or their parents or guardians) have given their written informed consent and the study protocol was approved by the local institution committee (Adana city training and research hospital Clinical research ethics committee. Date: 06/19/2018, Decision Nr: 14-212)

\section{Author Contributions:}

Concept: MAT, IEÖ

Literature Review: MAT

Design : MAT

Data acquisition: MAT, IEÖ

Analysis and interpretation: MAT, IEÖ

Writing manuscript: MAT, IEÖ
Critical revision of manuscript: MAT, IEÖ

Conflict of Interest: The authors have no conflicts of interest to declare.

Financial Disclosure: Authors declared no financial support.

\section{References}

1. Liman ŞT, Eliçora A, Akgül AG, Topcu S, Özbay $S$, Mehmetoğlu SS, et al. Is A Small-Bore Catheter Efficient For Most Pleural Pathologies? Surg Today 2014;44:834-838.

2. Light RW. Pleural controversy: Optimal chest tube size for drainage. Respirology 2011;16:244-248.

3. Cooke DT, David EA. Large-Bore and Small Bore Chest Tubes Types, Function, and Placement. Thorac Surg Clin 2013;23:17-24.

4. Öztürk CA. Small-Bore Thoracic Catheters. Plevra Bülteni 2012;6(1):10-14.

5. Cho S, Lee EB. Management of primary and secondary pneumothorax using a small-bore thoracic catheter. Interact CardioVasc Thorac Surg 2010;11:146-9.

6. Ayan E, Köksel MO, Bayülgen A, Arslan B. Küçük çaplı plevral kateter uygulamalarımı: 325 olgunun analizi. Mersin Üniv Sağlık Bilim Derg 2020;13:126-131.

7. Özsoy IE, Tezcan MA. A Thorough View of Tube Thoracostomy, The Most Common Surgical Procedure Performed by Thoracic Surgery Clinics: Ten Years' Clinical Experience. JAMER 2019;4(3):76-81.

8. Marel M. Epidemiology of pleural effusion. Eur Respir Mon 2002;22:146-56.

9. Light RW, Rogers JT, Moyers JP, Lee GC, Rodriguez RM, Alford WC et al. Prevalence and clinical course of pleural effusions at 30 days after coronary artery and cardiac surgery. Am J Respir Crit Care Med 2002;166: 1567-71.

10. Kochanek KD, Murphy SL, Xu J, Arias E.National vital statistics. Deaths: Final Data for 2017. Available from: https://www.cdc.gov/nchs/data/nvsr/nvsr68/nvsr68_09508.pdf

11. Light RW, Pleural Effusion Due to Miscellaneous Diseases. Pleural Disease Light RW ed. Philadelphia Lippincott Williams and Wilkins, 4th ed.: 2007:294-306

12. Putnam JB, Garrett LW, Swisher SG, Roth JA, Suell DM, Vaporciyan AA et al. Outpatient management of malignant pleural efusion by a chronic indwelling pleural catheter. Ann Thorac Surg 2000;69:369-75.

13. Asopa S, Patel A. Bonnano's catheter: A less invasive and cost-effective alternative for drainage of pleural effusion. J Thorac Cardiovasc Surg 2006;132:1503-4.

14. Keeling $N$, Leong $S$, Logan PM, Lee MJ. Empyema and Effusion: Outcome of Image-Guided Catheter Drainage. Cardiovasc Intervent Radiol 2008;31:135-41.

15. Filosso PL, Guerrera F, Sandri A, Roffinella M, Solidoro $P$, Ruffini $E$, et al. Errors and Complications in Chest Tube Placement. Thorac Surg Clin 2017;27:57-67.

16. Hallifax RJ, Psallidas I, Rahman NM. Chest Drain Size: The Debate Continues. Curr Pulmonol Rep 2017;6:26-9.

17. Vetrugno L, Guadagnin GM, Barbariol F, D'Incà $S$, Delrio $S$, Girometti R, et al. Assesment of Pleural Effusion and Small Pleural Drain Insertion by Resident Doctors in an Intensive Care Unit: An Observational Study. Clinical Medicine Insights: Circulatory, Respiratory and Pulmonary Medicine 2019;13:1-10. 